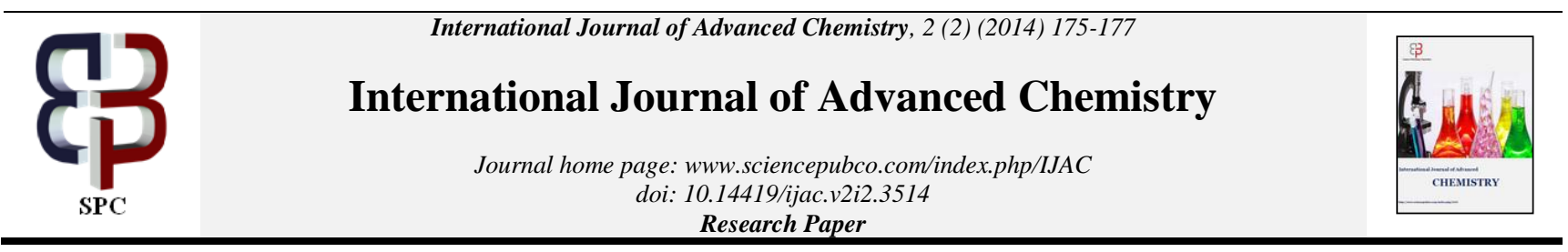

\title{
Phytochemical sreening, proximate analysis and mineral composition of some leafy vegetables consumed in Nigeria
}

\author{
Idoko O *, Emmanuel SA, Aguzue OC, Akanji FT, Thomas SA, Osuagwu I \\ Sheda Science and Technology Complex, Km 10, Abuja-Lokoja Road, Sheda, Abuja \\ *Corresponding author E-mail: idokoowoicho@yahoo.ie
}

\begin{abstract}
Phytochemical screening, proximate analysis and mineral composition of nine leafy vegetables; Teifaria occidentalis, Veronia amygdalina, Ocinum gratissimum, Corchorus olitorius, Piper guineese, Amaranthus hybridus Talinum triangulare, Gnetum africanum and Murraya koenigii was carried out using standard methods. The proximate analysis results showed that the moisture, ash, crude lipid, crude fibre, crude protein and carbohydrate ranged as followed; 10.20 to $15.17 \%, 6.65$ to $28.33 \%, 1.44$ to $11.29 \%, 0.52$ to $2.33 \% 2.24$ to $35.21 \%$ and 22.66 to $62.80 \%$ respectively. The mineral composition results showed that on the average, highest concentration of calcium was recorded in the range of 838 to $1258 \mathrm{mg} / 100 \mathrm{~g}$, while Cr was found to be the least with concentration range of 0.19 to $0.48 \mathrm{mg} / 100 \mathrm{~g}$. $\mathrm{Cd}$ was absent in all the samples. The phytochemical screening results also showed the presence of tannin, alkaloids and carbohydrate in all the leafy vegetables. The result of this study indicates that the leafy vegetables could be a good supplement for some the nutrients and elements analyzed.
\end{abstract}

Keywords: Leafy Vegetables, Mineral Composition, Phytochemicals, Proximate Analysis

\section{Introduction}

Leafy vegetables are important items of diet in many Nigerian homes. They are valuable sources of nutrients especially in rural areas where they contribute substantially to protein, mineral, vitamins, fiber and other nutrients which are usually in short supply in our daily diets (Mepba et al. 2007). The need for leafy vegetables in man's diet throughout the year cannot be overemphasized because aside providing nutrients to the body it also supplies some biologically active non-nutritive compounds which exhibit medicinal and physiological potentials. Consumption of fresh vegetable enables full assimilation of vitamins on the human body (Genderd 1994). The basic elements in leafy vegetables provide alkalizing effects, neutralizing the acidity caused by other foods of animal origin (Genderd 1994). Leafy vegetables contain both essential and toxic metals over a wide range of concentrations (Radwan \& Salama 2006). Some metals are essential and their deficiency results to biological malfunctions in the body but when present in excess, they become toxic (Soylak et al. 2003). The aim of this work is to ascertain the nutritive and the non-nutritive value as well as the metal composition of nine leafy vegetables consumed in Nigeria.

\section{Materials and methods}

\subsection{Sample collection and preparation}

The nine leafy vegetables used in this study were purchased from a local market in Gwagwalada Area Council of the Federal Capital Territory Abuja, Nigeria. The leaves were identified by the Chemistry Advanced Laboratory of Sheda Science and Technology
Complex, Abuja. The leaves were shade dried for 7 days ground into powder using pestle and mortar. The grounded portion was then stored in plastic containers prior to analysis.

\subsection{Proximate analysis}

Moisture, ash, crude fibre, crude fat, were determined using standard methods (AOAC 1999), protein was determined by the Kjeldahl method (Pearson 1976). Carbohydrate was determined by the difference.

\subsection{Phytochemical screening}

Chemical test were carried out on the aqueous extracts of the leafy vegetables to ascertain the presence of tannin, steroids, triterpenoids, glycosides, saponins, phenols, alkaloids, terpenoids, carbohydrate, flavonoids, cardiac glycosides, phlobatanins, resins, and balsams using method described by (Sofowora 1993).

\subsection{Mineral composition analysis}

Some portion of the dried powder samples was digested as reported by (Soylak et al. 2003). $1 \mathrm{~g}$ of each samples was weigh into separate beakers and treated with $12 \mathrm{ml}$ of $10 \mathrm{M} \mathrm{HNO} / \mathrm{H}_{2} \mathrm{O}_{2}(2: 1)$. The mixture was heated to $130^{\circ} \mathrm{C}$ for $4 \mathrm{hrs}$. After cooling, it was filtered into $100 \mathrm{ml}$ volumetric flask and the was made up with deionized water. The digests were analyzed for the minerals and trace metals content using ThermoScientific ICE 3000 Atomic Absorption Spectrophotometer. 


\section{Results and Discussions}

The proximate analysis of the leafy vegetables is shown in (Table 1). The moisture content ranges from $10.20 \%$ in Gnetum africanum to $15.17 \%$ in Talinum triangulare the moisture contents observed in the leaves provides for greater activity of water soluble enzymes and co-enzymes needed for metabolic activities of the vegetables (Iheanacho \& Ubebani 2009). The ash content varies from $6.65 \%$ in Gnetum africanum to $28.33 \%$ in Talinum triangulare. These results showed that there are more minerals in Talinum triangulare compared to the rest of the leaves investigated. The ash content of Teifaria occidentalis and Piper guineese shown is higher than the values reported by (Taiga et al. 2008). The crude lipid ranges from $1.44 \%$ in Teifaria occidentalis to $12.43 \%$ in Gnetum africanum. Crude lipids are the principal sources of energy but must be consumed with caution to avoid obesity and other related diseases. A diet providing 1-2\% of its caloric energy as fat is sufficient in human beings as excessive consumption have been implicated in certain cardiovascular disorders such as atherosclerosis cancer and aging (Antia et al. 2006). The crude lipid content in Veronia amygdalina (11.29\%) and Ocinum gratissimum (7.84\%) is higher than the values reported by (Asaolu et al. 2012). The crude fibre results ranges from $0.52 \%$ in Amaranthus hybridus to $2.33 \%$ in Murraya koenigii. The fibre content in Veronia amygdalina (2.33\%), Ocinum gratissinum $(0.73 \%)$ and Teifaria occidentalis $(1.17 \%)$ are lower compared to the values reported by (Taiga et al. 2008). Adequate intake of dietary fibre can lower cholesterol level, risk of coronary heart disease, hypertension, constipation, diabetes, colon and breast cancer (Rao \& Newmark 1998). The protein content as reported in this work varies from $1.82 \%$ in Talinum triangulare to $35.12 \%$ in Teifaria occidentalis. The protein content of Teifaria occidentalis, Amaranthus hybridus and Veronia amygdalina is within the range of 20.48 to $41.66 \%$ reported by (Roger et al. 2005). Crude protein content greater than $30 \%$ of leafy vegetables indicates that it is a good source of protein supplement to meet the recommended daily requirement (RDA) for humans (FND 2002). The carbohydrate content is in the range of 22.6 to $62.80 \%$ which is relatively high compared to similar work reported by (Iniaghe et al. 2009, Asaolu et al. 2012 \& Oko AO 2012). The results of the phytochemical screening (Table 2) shows the presence of tannins, carbohydrate and alkaloids and the absence of resins, phlobatannins and flavonoids in all the samples studied. Tannin found in all is of high importance in the treatment of hereditary hemochromatosis (Sofowora 1993). The presence of phenol, saponins in some of the leaves and alkaloids in all the leaves are known to exhibit medicinal and physiological activity (Rao \& Newmark 1998). Steroids present in Amaranthus hybridus; Murraya koenigii and piper guineese are of importance and interest in pharmacy due to their relationship with some compounds as sex hormones (Okwu 2001). Cardiac glycosides found in Ocinum gratissimum, Murraya koenigii and Corchorus olitorious can be used to treat heart diseases like congestive heart failures and cardiac arrhythmia (Okwu 2001). Balsams are oily or gummy oleoresisns found in various pleasantly scented plant products (Iniaghe et al. 2009). This is confirmed as it is detected only in Ocinum gratissimum and Murraya koenigii.

The results of mineral composition were shown in (Table 3). The $\mathrm{Fe}$ content range from $3.80 \mathrm{mg} / 100 \mathrm{~g}$ in Ocinum gratissimum to $28.50 \mathrm{mg} / 100 \mathrm{~g}$ in Teifaria occidentalis. The concentration of $\mathrm{Fe}$ in Veronia amygdalina and Corchorus olitorius in the work is lower compared to the $27.7 \mathrm{mg} / 100 \mathrm{~g}$ and $84 \mathrm{mg} / 100 \mathrm{~g}$ reported by (Anyoola et al. 2010), 28mg/100g and $38 \mathrm{mg} / 100 \mathrm{~g}$ reported by (Mohammed \& Sharif 2011), respectively. Fe is important in the diet especially for pregnant and nursing mothers as well as infants (Dioxon \& Haris 2003). Deficiency in Fe will lead to reduced work capacity, impairment in behavior and intellectual performance and decrease resistance to infection (Dioxon \& Haris 2003). The $28.50 \mathrm{mg} / 100 \mathrm{~g}, 26.20 \mathrm{mg} / 100 \mathrm{~g}$ and $22.30 \mathrm{mg} / 100 \mathrm{~g}$ of Teifaria occidentalis, Veronia amygdalina and Talinum triangulare respectively could contribute greatly to the recom- mended daily allowance of $\mathrm{Fe}(10-15 \mathrm{mg} /$ day). $\mathrm{Zn}$ content range between $1.44 \mathrm{mg} / 100 \mathrm{~g}$ in Piper guineese to $9.61 \mathrm{mg} / 100 \mathrm{~g}$ in Murraya koenigii. $\mathrm{Zn}$ is essential for nerve function and male fertility. It is important for normal sexual development of testes and ovaries (Anyoola et al. 2010). Regular consumption of these leafy vegetables most especially Murraya koenigii may assist in the preventing the effect of $\mathrm{Zn}$ deficiency such as retarded growth and delayed sexual maturation (Barminas et al. 1998). Ca content of the leafy vegetables range from $838 \mathrm{mg} / 100 \mathrm{~g}$ in Gnetum africanum to $1258 \mathrm{mg} / 100 \mathrm{~g}$ in Amaranthus hybridus. The Ca content recorded in this work is very high and could help to prevent osteroporosis, arthritis,pyorrhea, rickets and tooth decay when consumed daily. The $\mathrm{Mg}$ content of the leafy vegetables is relatively high ranging between 56.38 to $60.50 \mathrm{mg} / 100 \mathrm{~g}$. Talinum triangulare had the highest $\mathrm{Mg}$ content. The $\mathrm{Mg}$ content of Corchorus olitorius, Ocinum gratissimum, Amaranthus hybridus and Teifaria occidentalis are lower compared to a similar work reported by (Asaolu et al. 2012). Mg helps in energy metabolism, protein synthesis, RNA and DNA synthesis and maintenance of electrical potential of nerves tissues (FAO/WHO 2003). The Mn content range from $1.94 \mathrm{mg} / 100 \mathrm{~g}$ in Piper guineese to $80.30 \mathrm{mg} / 100 \mathrm{~g}$ in Gnetum africanum. This work reported $8.25 \mathrm{mg} / 100 \mathrm{~g}$ in Veronia amygdalina and $10 \mathrm{mg} / 100 \mathrm{~g}$ in Corchorus olitorius which is lower compared to the work reported by (Mohammed \& Sharif 2011). The concentration of some heavy metals recorded in this work $\mathrm{Cr}(0.19-0.48 \mathrm{mg} / 100 \mathrm{~g})$ and $\mathrm{Pb}(\mathrm{nd}-$ $2.34 \mathrm{mg} / 100 \mathrm{~g}$ ) is low and $\mathrm{Cd}$ is absent in all the leafy vegetables while Ni is found in Talinum triangulare and Gnetum Africanum to be $0.20 \mathrm{mg} / 100 \mathrm{~g}$ and $0.22 \mathrm{mg} / 100 \mathrm{~g}$ respectively.

Table 1: Proximate Analysis Results of the Leafy Vegetable

\begin{tabular}{|c|c|c|c|c|c|c|c|}
\hline \multirow[b]{2}{*}{$\begin{array}{l}\mathrm{S} / \\
\mathrm{N}\end{array}$} & \multirow[b]{2}{*}{$\begin{array}{l}\text { Leafy } \\
\text { Vegetables }\end{array}$} & \multicolumn{6}{|c|}{ Parameter (\%) Of Dried Leaves } \\
\hline & & Ash & $\begin{array}{l}\text { Mois- } \\
\text { ture }\end{array}$ & $\begin{array}{l}\text { Li- } \\
\text { pid }\end{array}$ & $\begin{array}{l}\text { Fi- } \\
\text { bre }\end{array}$ & $\begin{array}{l}\text { Pro- } \\
\text { tein }\end{array}$ & $\begin{array}{l}\text { Carbohy- } \\
\text { drate }\end{array}$ \\
\hline 1 & $\begin{array}{l}\text { Teifaria } \\
\text { occidentali } \\
\mathrm{s}\end{array}$ & $\begin{array}{l}12.7 \\
3\end{array}$ & 13.85 & 1.44 & 1.17 & 35.21 & 35.60 \\
\hline 2 & $\begin{array}{l}\text { Amaranthu } \\
\text { s hybridus }\end{array}$ & $\begin{array}{l}22.4 \\
2\end{array}$ & 14.65 & 7.46 & 0.52 & 31.02 & 22.66 \\
\hline 3 & $\begin{array}{l}\text { Ocinum } \\
\text { gratissimu } \\
\mathrm{m}\end{array}$ & $\begin{array}{l}12.1 \\
2\end{array}$ & 13.99 & 7.84 & 0.73 & 2.62 & 62.70 \\
\hline 4 & $\begin{array}{l}\text { Murraya } \\
\text { koenigii }\end{array}$ & $\begin{array}{l}11.5 \\
3\end{array}$ & 14.36 & $\begin{array}{l}10.0 \\
9\end{array}$ & 2.33 & 2.86 & 58.83 \\
\hline 5 & $\begin{array}{l}\text { Veronia } \\
\text { amygdalin } \\
\text { a }\end{array}$ & $\begin{array}{l}15.7 \\
7\end{array}$ & 15.11 & $\begin{array}{l}11.2 \\
9\end{array}$ & 1.40 & 20.70 & 35.73 \\
\hline 6 & $\begin{array}{l}\text { Gnetum } \\
\text { africanum }\end{array}$ & 6.65 & 10.20 & $\begin{array}{l}12.4 \\
3\end{array}$ & 1.13 & 12.94 & 56.65 \\
\hline 7 & $\begin{array}{l}\text { Corchorus } \\
\text { olitorius }\end{array}$ & $\begin{array}{l}13.7 \\
2\end{array}$ & 14.24 & 5.19 & 0.55 & 3.50 & 62.80 \\
\hline 8 & $\begin{array}{l}\text { Piper } \\
\text { guineese }\end{array}$ & $\begin{array}{l}20.9 \\
2\end{array}$ & 10.67 & 7.25 & 1.18 & 2.24 & 57.74 \\
\hline 9 & $\begin{array}{l}\text { Talinum } \\
\text { triangulare }\end{array}$ & $\begin{array}{l}28.3 \\
3\end{array}$ & 15.17 & 8.07 & 1.34 & 1.82 & 45.27 \\
\hline
\end{tabular}

Table 2: Phytochemical Constituents of Aqueous Extract of the Leafy Vegetables

\begin{tabular}{|c|c|c|c|c|c|c|c|c|c|c|}
\hline \multirow{3}{*}{$\begin{array}{l}\mathrm{S} / \\
\mathrm{N}\end{array}$} & \multirow{3}{*}{$\begin{array}{l}\text { CONSTITU- } \\
\text { ENTS }\end{array}$} & \multicolumn{9}{|c|}{ LEAFY VEGETABLES } \\
\hline & & $\mathrm{T}$ & A & $\mathrm{O}$ & M & V & G & $\mathrm{C}$ & $\mathrm{P}$ & $\mathrm{T}$ \\
\hline & & $\mathrm{O}$ & $\mathrm{h}$ & $\mathrm{C}$ & $\mathrm{k}$ & $\mathrm{a}$ & $\mathrm{a}$ & o & $\mathrm{g}$ & $\mathrm{t}$ \\
\hline 1 & Tannin & + & + & + & + & + & + & + & + & + \\
\hline 2 & Steroids & - & + & - & + & - & - & - & + & - \\
\hline 3 & Triterperoids & - & + & - & - & + & - & + & + & + \\
\hline 4 & Glycosides & - & - & - & + & - & - & - & - & - \\
\hline 5 & Saponius & + & + & + & + & + & - & - & + & + \\
\hline 6 & Phenols & + & + & - & - & - & + & - & - & - \\
\hline 7 & Alkaloids & + & + & + & + & + & + & + & + & + \\
\hline 8 & Terpenoids & + & + & + & + & - & - & - & - & - \\
\hline 9 & Carbohydrate & + & + & + & + & + & + & + & + & + \\
\hline 10 & Flavonoids & - & - & - & - & - & - & - & - & - \\
\hline 11 & $\begin{array}{l}\text { Cardia Glyco- } \\
\text { sides }\end{array}$ & - & - & + & + & - & - & + & - & - \\
\hline 12 & Phlobatannius & - & - & - & - & - & - & - & - & - \\
\hline 13 & Resins & - & - & - & - & - & - & - & - & - \\
\hline 14 & Balsams & - & - & + & + & - & - & - & - & - \\
\hline
\end{tabular}

gratissimum; $\mathrm{Mk}=$ Murraya koenigii; $\mathrm{Va}=$ Veronia amygdalina; $\mathrm{Ga}=$ Gnetum

africanum; $\mathrm{Co}=$ Corchorus olitorius; $\mathrm{Pg}=$ Piper guineese; $\mathrm{Tt}=$ Talinum triangulare

+ Defected

- Not defected 
Table 3: Mineral Composition of the Leafy Vegetables

\begin{tabular}{|c|c|c|c|c|c|c|c|c|c|c|}
\hline \multirow{2}{*}{$\begin{array}{l}\mathrm{S} / \\
\mathrm{N}\end{array}$} & \multirow{2}{*}{$\begin{array}{l}\text { SAM- } \\
\text { PLES }\end{array}$} & \multicolumn{9}{|c|}{ Mineral Composition $(\mathrm{Mg} / 100 \mathrm{~g})$} \\
\hline & & $\mathrm{Fe}$ & $\mathrm{Zn}$ & $\mathrm{Cr}$ & $\mathrm{Ca}$ & $\mathrm{Ni}$ & $\begin{array}{l}\text { C } \\
\text { d }\end{array}$ & $\mathrm{Mg}$ & $\mathrm{Pb}$ & $\mathrm{Mn}$ \\
\hline 1 & $\begin{array}{l}\text { Teifaria } \\
\text { occident } \\
\text { alis }\end{array}$ & $\begin{array}{l}28 . \\
50\end{array}$ & $\begin{array}{l}6.3 \\
7\end{array}$ & $\begin{array}{l}0.3 \\
2\end{array}$ & $\begin{array}{l}922.9 \\
0\end{array}$ & - & - & $\begin{array}{l}60 . \\
21\end{array}$ & $\begin{array}{l}1.8 \\
3\end{array}$ & $\begin{array}{l}19 . \\
37\end{array}$ \\
\hline 2 & $\begin{array}{l}\text { Amarant } \\
\text { hus } \\
\text { hybridus }\end{array}$ & $\begin{array}{l}12 . \\
90\end{array}$ & $\begin{array}{l}5.4 \\
0\end{array}$ & $\begin{array}{l}0.2 \\
9\end{array}$ & $\begin{array}{l}1258 . \\
00\end{array}$ & - & - & $\begin{array}{l}60 . \\
30\end{array}$ & $\begin{array}{l}2.0 \\
4\end{array}$ & $\begin{array}{l}18 . \\
60\end{array}$ \\
\hline 3 & $\begin{array}{l}\text { Ocinum } \\
\text { gratissim } \\
\text { um }\end{array}$ & $\begin{array}{l}3.8 \\
0\end{array}$ & $\begin{array}{l}1.8 \\
2\end{array}$ & $\begin{array}{l}0.1 \\
9\end{array}$ & $\begin{array}{l}1219 . \\
00\end{array}$ & - & - & $\begin{array}{l}56 . \\
38\end{array}$ & - & $\begin{array}{l}5.0 \\
0\end{array}$ \\
\hline 4 & $\begin{array}{l}\text { Murraya } \\
\text { koenigii }\end{array}$ & $\begin{array}{l}9.6 \\
0\end{array}$ & $\begin{array}{l}9.6 \\
1\end{array}$ & $\begin{array}{l}0.4 \\
0\end{array}$ & $\begin{array}{l}1228 . \\
00\end{array}$ & - & - & $\begin{array}{l}59 . \\
36\end{array}$ & $\begin{array}{l}2.3 \\
3\end{array}$ & $\begin{array}{l}2.9 \\
6\end{array}$ \\
\hline 5 & $\begin{array}{l}\text { Veronica } \\
\text { amygdali } \\
\text { na }\end{array}$ & $\begin{array}{l}26 . \\
20\end{array}$ & $\begin{array}{l}6.1 \\
0\end{array}$ & $\begin{array}{l}0.4 \\
1\end{array}$ & $\begin{array}{l}871.2 \\
0\end{array}$ & - & - & $\begin{array}{l}59 . \\
79\end{array}$ & $\begin{array}{l}2.0 \\
5\end{array}$ & $\begin{array}{l}8.2 \\
5\end{array}$ \\
\hline 6 & $\begin{array}{l}\text { Gnetum } \\
\text { africanu } \\
\mathrm{m}\end{array}$ & $\begin{array}{l}17 . \\
00\end{array}$ & $\begin{array}{l}2.6 \\
0\end{array}$ & $\begin{array}{l}0.4 \\
2\end{array}$ & $\begin{array}{l}838.0 \\
0\end{array}$ & $\begin{array}{l}0.2 \\
2\end{array}$ & - & $\begin{array}{l}58 . \\
24\end{array}$ & $\begin{array}{l}2.3 \\
4\end{array}$ & $\begin{array}{l}80 . \\
30\end{array}$ \\
\hline 7 & $\begin{array}{l}\text { Corchoru } \\
\mathrm{s} \\
\text { olitorius }\end{array}$ & $\begin{array}{l}7.6 \\
0\end{array}$ & $\begin{array}{l}4.5 \\
4\end{array}$ & $\begin{array}{l}0.4 \\
4\end{array}$ & $\begin{array}{l}949.0 \\
0\end{array}$ & - & - & $\begin{array}{l}59 . \\
70\end{array}$ & $\begin{array}{l}1.0 \\
0\end{array}$ & $\begin{array}{l}10 . \\
00\end{array}$ \\
\hline 8 & $\begin{array}{l}\text { Piper } \\
\text { guineese }\end{array}$ & $\begin{array}{l}18 . \\
30\end{array}$ & $\begin{array}{l}1.4 \\
4\end{array}$ & $\begin{array}{l}0.2 \\
7\end{array}$ & $\begin{array}{l}1254 . \\
00\end{array}$ & - & - & $\begin{array}{l}59 . \\
14\end{array}$ & $\begin{array}{l}0.4 \\
0\end{array}$ & $\begin{array}{l}1.9 \\
4\end{array}$ \\
\hline 9 & $\begin{array}{l}\text { Talinum } \\
\text { triangula } \\
\text { re }\end{array}$ & $\begin{array}{l}22 . \\
30\end{array}$ & $\begin{array}{l}5.9 \\
8\end{array}$ & $\begin{array}{l}0.4 \\
8\end{array}$ & $\begin{array}{l}839.5 \\
0\end{array}$ & $\begin{array}{l}0.2 \\
0\end{array}$ & - & $\begin{array}{l}60 . \\
50\end{array}$ & $\begin{array}{l}0.7 \\
6\end{array}$ & $\begin{array}{l}25 . \\
97\end{array}$ \\
\hline
\end{tabular}

Table 4 shows the botanical, common and vernacular names of the nine leafy vegetables used in this study.

Table 4: The Botanical, Common English and Local Vernacular Names of Leafy Vegetables

\begin{tabular}{|c|c|c|c|}
\hline $\mathrm{S} / \mathrm{N}$ & $\begin{array}{l}\text { BOTANICAL } \\
\text { NAMES }\end{array}$ & $\begin{array}{l}\text { COMMON } \\
\text { ENGLISH NAMES }\end{array}$ & $\begin{array}{l}\text { LOCAL VERNACULAR } \\
\text { NAMES }\end{array}$ \\
\hline 1 & Teifaria occidentalis & Fluted pumpkin & Ugu \\
\hline 2 & $\begin{array}{l}\text { Amaranthus } \\
\text { hybridus }\end{array}$ & African spinach & Alefo, Efotete \\
\hline 3 & $\begin{array}{l}\text { Ocinum } \\
\text { gratissimum }\end{array}$ & Scent leaf & Efirin, Nahianwu, Daidoya \\
\hline 4 & Murraya koenigii & Curry & \\
\hline 5 & $\begin{array}{l}\text { Veronica } \\
\text { amygdalina }\end{array}$ & Bitter leaf & Efo ewuro, \\
\hline 6 & Gnetum africanum & - & Okazi, Ukazi, Afang \\
\hline 7 & Corchorus olitorius & $\begin{array}{l}\text { Jute leaf, Mallow } \\
\text { leaves }\end{array}$ & Ewedu, Rama \\
\hline 8 & Piper guineese & - & Oziza, Uziza \\
\hline 9 & Talinum triangulare & Water leaf & Gbure \\
\hline
\end{tabular}

\section{Conclusion}

The proximate analysis indicates that the nine leafy vegetables investigated are very rich in carbohydrate and a good source of energy. This work also showed that Teifaria occidentalis, Amaranthus hybridus and Veronia amygdalina are good source of protein. The presence of some biologically active non-nutritional components can serve as a potential source of useful drugs. The mineral composition indicates that the leafy vegetables is a good source of minerals and make significant contribution to the recommended dietary allowance for the minerals most especially $\mathrm{Ca}$ $\mathrm{Mg}, \mathrm{Mn}$ and $\mathrm{Fe}$.

\section{References}

[1] Mepba HD, Eboh L \& Banigo DEB (2007) Effects of processing treatments on the nutritive composition and consumer acceptance of some Nigerian edible leafy vegetables.Afri. J. Food Agri. Nutri. Dev.; 7(1), 1684-5374.

[2] AOAC (1999) Official methods of analysis Association of official analytical chemists. 21st ed. Washington D.C. USA

[3] Pearson D (1976) Chemical analysis of food.7th ed. Churchill, London 7-11.

[4] Sofowora A (1993) Medical plants and traditional medicine in Africa. Spectrum Books Ltd., Ibadan, Nigeria 289.

[5] Iheanacho K \& Ubebani AC (2009) Nutritional composition of some leafy vegetable consumed in Imo State, Nigeria. J. Appl. Sci. Environ Manage. 13(3), 35-38.
[6] Antia BS, Akpan EJ, Okon PA \& Umoren IU (2006) Nutritive and anti-nutritive evaluation of sweet Potatoes (Ipomoea batatas) leaves. Pak. J. Nutri. 15, 166-168.

[7] Asaolu SS, Adefemi OS, Oyakilome IG, Ajibulu KE \& Asaolu (2012) MF Proximate and mineral composition of Nigerian leafy vegetables. J. Food Res. 1(3), 214-218. http://dx.doi.org/10.5539/jfr.v1n3p214.

[8] Taiga A, Suleiman MN, Aina DO, Sule WF \& Alege GO (2008) Proximate analysis of some dry season vegetables in Ayigba, Kogi State, Nigeria. Afri. J. Biotechnol. 7(10), 1588-1590.

[9] Rao CV \& Newmark HL (1998) Chemo-preventive effect of squalene on colon cancer. Carcinogenesis. 19, 287-290. http://dx.doi.org/10.1093/carcin/19.2.287.

[10]Roger P, Elie F, Rose L, Martin F, Jacob S, Mercy AB \& Felicia MT (2005) Methods of preparation and nutritional evaluation of dishes consumed in a malaria endemic zonein Cameroon (Ngali II). Afri. J. Biotechnol. 4(3), 273-278.

[11]FND (2002) Dietary reference intake for energy, carbohydrate, fibre, fats, fatty acids cholesterol, protein and amino acid (micronutrients). National Acedemy of Science, USA.

[12] Iniaghe OM, Malomo SO \& Adebayo JO (2009) Proximate composition and phytochemical constituents of leaves of some Acalypha spe$\begin{array}{llll}\text { cies. Pak. J. } & \text { Nutri. }\end{array}$ http://dx.doi.org/10.3923/pjn.2009.256.258

[13]Oko AO (2012) Nutritional and phytochemical composition of the leaves of Mucuna poggei. J. Biol Life Sci. 3(1), 232-242. http://dx.doi.org/10.5296/jbls.v3i1.2218.

[14] Okwu DE (2001) Evaluation of the chemical of indigenous spices and flavouring agents. Global J. Pure Appl. Sci. 7, 455-459.

[15]Genderd R (1994) Scented flora of the world. Robert Hale. London.

[16]Radwan MA \& Salama AK (2006) Market basket survey for some heavy metals in Egyptian fruits and vegetables. Food Chemistry and 44 , 1273-1278. http://dx.doi.org/10.1016/j.fct.2006.02.004.

[17] Soylak M, Tuzen M, Narin I \& Sari H (2003) Comparison of microwave dry and wet digestion procedures for the determination of trace metal contents of spice produced in Turkey. J. Food Drug Anal. 12: 254-258.

[18] Anyoola PB, Adeyeye a \& Onawumi OO (2010) Trace element and major evaluation of Spondias mombin, Veronia amygdalina and Momordia charantia leaves. Pak. J. Nutri. 9(8), 755-758. http://dx.doi.org/10.3923/pjn.2010.755.758.

[19]Mohammed MI \& Sharif N (2011) Mineral composition of some leafy vegetables consumed in Kano, Nigeria. Nigerian Journal of Basic and Applied Sciences. 19(2), 208-212.

[20]Dioxon BM \& Haris EM (2004) Nigeria food consumption and nutrition survey. 2001-2003

[21]FAO/WHO (2002) Report of a joint FAO/WHO. Expert consultation on human vitamin and mineral requirements. Expert Consultation, Bankok, Thailand. 223-229.

[22]Barminas JT, Charles M \& Emmanuel D (1998) Mineral composition of non-conventional leafy vegetables. Plant Foods for Human nutrition. 53: 29-36. http://dx.doi.org/10.1023/A:1008084007189. 